\title{
ATO DE LEITURA, ATOS DE IMAGINAÇÃO: PERSONAGENS LEITORES EM MADAME BOVARY
}

\author{
Hêmille Raquel Santos Perdigão ${ }^{1}$
}

RESUMO: O presente trabalho apresenta as teorias do ato de leitura defendidas por Wolfgang Iser e as relaciona ao romance Madame Bovary, de Flaubert. O objetivo é mostrar que tanto a leitura da realidade quanto a da ficção envolvem as experiências pessoais, que interferem nos atos de imaginação de cada personagem. Para isso, são apresentados excertos do romance Madame Bovary nos quais é abordado o tema da leitura, seja da ficção ou da realidade. A conclusão foi que, de fato, os personagens do clássico francês têm suas leituras dos romances e de suas vidas interferidas por experiências, sejam experiências que eles adquiriram em acontecimentos vividos ou lidos.

PALAVRAS-CHAVE: Ato de leitura. Leitores. Ficção. Realidade.

Acreditam que estou apaixonado pelo real, quando eu o execro; já que foi por ódio ao realismo que empreendi este romance. Mas não detesto menos a falsa realidade com a qual somos afligidos em nossa época. (FLAUBERT, 2005, p. 156).

O excerto acima é de uma correspondência entre Flaubert e uma leitora. O ódio ao Realismo, a que se refere, é o Realismo que considera os romances como espelhos da vida e que persuadem o leitor a crer nisso. Flaubert rompe com essa tendência ao escrever um "livro sobre o que livros fazem com os leitores de livros", tendo, segundo Hugh Kenner, "one eye always on the sort of thing his own book is going to do to its own reader "(KENNER, 2005, p. 23). ${ }^{2}$ O livro em questão é o clássico Madame Bovary, um romance que, dentre outras questões, aborda os efeitos da leitura na protagonista Emma Bovary.

Considere-se, então, essa questão levantada por Hugh Kenner: o que os livros fazem com seus leitores? Os leitores de ficção são maus ou bons leitores da realidade? Para responder esses questionamentos, deve-se partir da primeira relação entre realidade e ficção existente: a do autor com a realidade. Wolfgang Iser explica:

O texto literário se origina da reação de um autor ao mundo e ganha o caráter de acontecimento à medida que traz uma perspectiva para o mundo presente que não está nele contida. Mesmo quando um texto literário não faz senão copiar o mundo presente, sua repetição no texto já o altera, pois repetir a realidade a partir de um ponto de vista já é excedê-la. Em princípio, a reação do autor ao mundo, que se ma-

1 Instituição: Universidade Federal de Ouro Preto, Orcid: http://orcid.org/0000-0002-7832-5572, E-mail: hrsperdigao@yahoo.com.br

2 um olho sempre no tipo de coisa que seu próprio livro vai fazer com seu próprio leitor. (Tradução minha). 
nifesta no texto, rompe as imagens dominantes no mundo real, os sistemas sociais e de sentido, as interpretações e as estruturas. (ISER, 1996, p. 11)

Assim, no momento em que o autor reproduz a realidade, por mais fiel que seja a sua intenção, as imagens do mundo real são rompidas, de modo que as imagens contidas nas páginas da ficção são outras, totalmente independentes da realidade:

Pois ela [a imagem] não descreve algo existente de antemão, mas sim concretiza uma representação daquilo que não existe e que não se manifesta verbalmente nas páginas impressas do romance. (ISER, 1996, p. 32)

Se as imagens do texto ficcional não coincidem com a realidade na qual o autor se pautou e, segundo Iser, sequer estão manifestas verbalmente nas páginas do romance, qual a procedência das imagens ficcionais? A resposta é: são formadas na consciência imaginativa do leitor.

O sentido do texto é apenas imaginável, pois ele não é dado explicitamente; em consequência, apenas na consciência imaginativa do receptor se atualizará. No processo da leitura emerge uma sequência de tais atos de imaginação (ISER, 1996, p. 76)

Dessa forma, não há um sentido único e verdadeiro em um texto; a leitura de uma ficção e as imagens constituídas durante a leitura variam de leitor para leitor, visto que cada qual, no seu ato de leitura, tem seus respectivos atos imaginativos, os quais dependem das experiências individuais.

sentimos no final da leitura a vontade de relacionar essa experiência estranha ao horizonte de nossas ideias; esse horizonte dirigiu, de forma latente, nossa disposição de responder ao texto.

Daí segue que o papel do leitor se realiza histórica e individualmente, de acordo com as vivências e a compreensão previamente constituída que os leitores introduzem na leitura. (ISER, 1996, p. 77-8)

Flaubert explora isso bem em Madame Bovary. Os personagens flaubertianos são como os balzaquianos, porém "in the mode of failure rather than success" 3(BROOKS, 1992, p. 176), o que Flaubert faz questão de destacar, mostrando que a leitura dos romances realistas de Balzac não torna seus personagens mais sábios. As ricas explicações do narrador balzaquiano não impedem que os personagens de Flaubert sejam maus leitores da realidade, uma vez que o sentido do texto não depende da fidelidade de Balzac ao representar a realidade e nem da realidade que Balzac fielmente descreve, mas depende, sim, dos atos de imaginação do leitor, os quais estão relacionados às suas experiências:

Mas como o horizonte de sentido nem copia algo dado do real, nem do hábito de um público intencionado, o leitor deve imaginá-lo. Apenas a imaginação é capaz de captar o não-dado, de modo que a estrutura do texto, ao estimular uma sequência de imagens, se traduz na consciência receptiva do leitor. O conteúdo dessas imagens continua sendo afetada pelas experiências dos leitores. Essas experiências constituem o quadro de referências que permite apropriar-se do não-familiar ou ao menos fundamentar sua imagem. A concepção do leitor implícito descreve, portanto, um processo de transferência pelo qual as estruturas do texto se traduzem nas experiências do leitor através dos atos de imaginação. (ISER,1996, p. 79)

3 no modo de falha ao invés de sucesso. (Tradução minha). 
As explanações de Iser se aplicam a leitores reais de ficções. Todavia, nesse trabalho, são utilizadas as mesmas teorias para analisar como os leitores ficcionais do romance de Flaubert, Madame Bovary, se comportam como leitores das ficções que eles leem e, também, como leitores da realidade ficcional em que vivem. Será visto que, na leitura da vida real, ocorre o mesmo que Iser explica sobre a leitura das ficções: se duas pessoas distintas, ao lerem o mesmo texto, formam imagens distintas a partir de suas experiências, analogamente, duas pessoas distintas, ao viverem uma mesma situação, terão leituras distintas do momento, de acordo com suas experiências; nisso consiste o realismo de Flaubert.

\title{
O LEITOR CHARLES BOVARY
}

Para dar início à análise dos personagens leitores de Madame Bovary, foi escolhida uma cena com Charles Bovary, ainda jovem e estudante de Medicina. A cena se passa anos antes de o personagem conhecer a protagonista do romance:

\begin{abstract}
Nas belas noites de verão, na hora em que as ruas mornas estão vazias, quando as criadas jogam peteca diante das portas, ele abria a janela e se acotovelava. $\mathrm{O}$ rio, que faz dessa parte do bairro uma ignóbil pequena Veneza, corria lá abaixo dele, amarelo, violeta ou azul, entre as pontes e suas grades. Operários, agachados à beira dele, lavavam os braços na água. Sobre jiraus partindo do alto dos sótãos, chumaços de algodão secavam ao ar livre. À frente, além dos telhados, o grande céu puro se estendia, com o sol vermelho se pondo. Como devia estar gostoso lá longe! Que frescor sob o bosque de faias! E ele abria as narinas para aspirar os bons cheiros do campo que não chegavam até ele. (FLAUBERT, 2017, p. 85)
\end{abstract}

A cena marca um momento em que o jovem tem desejos de estar em um ambiente diferente do seu, mais precisamente, o ambiente do qual ele é separado por uma janela. O que ele vê são operários que se movimentam, o que é contrário à sua natureza, visto que, desde a cena inicial do romance, fica evidente que ele tem seus movimentos limitados. Charles tinha uma ambição de liberdade e, por isso, abriu a janela. Porém, ele permanece acotovelado nela, em uma atitude corporal de comodismo. Não há, portanto, tentativas de se vincular à realidade nem mesmo tentativas de alcançar a liberdade almejada.

Anos depois, Charles se casa com Emma, protagonista do romance. O casamento dos dois é, para a moça, algo cansativo, monótono e marcado pelas falhas de leitura da realidade pelo marido, que acredita que ambos estão vivendo um matrimônio perfeito. Segue uma cena em que tal situação é evidenciada:

Ele se levantava. Ela se punha à janela para vê-lo ir-se embora; e ficava acotovelada
à beirada, entre dois vasos de gerânio, vestida com o seu peignoir, que lhe ficava largo
no corpo. Charles, na rua, colocava as esporas no meio-fio; e ela continuava a falar
com ele do alto, enquanto arrancava com a boca algum fiapo de flor ou de planta, que
assoprava na direção dele, e que voejava, sustentando-se, fazendo no ar semicírculos
como um pássaro, ia, antes de cair, agarrar-se à crina mal penteada da velha égua
branca, imóvel à porta. Charles, a cavalo, jogava-lhe um beijo; ela respondia com um
sinal, fechava a janela, ele se ia. (FLAUBERT, 2017, p. 113).

A roupa de Emma, de tamanho largo, é uma metonímia da inadequação da situação. Nessa cena, Emma se assemelha a Charles, tanto pelo tamanho errado do peignor quanto pelo acotovelamento na janela, mostrado na cena supracitada. O jovem Charles estava pensando em sua insatisfação com a vida atual, mas o adulto Charles, quando vê a esposa na mesma 
posição de insatisfação que ele mesmo tivera, não consegue fazer a leitura da situação e não compreende o tédio da esposa. Esquece que, no passado, quando ele ficava dessa mesma forma, acotovelado na janela, estava infeliz, almejando algo que estava mais longe. Assim, ele apenas interpreta a posição da mulher como uma atitude amorosa.

É importante destacar, nessa cena, como o narrador deixa evidências sutis das características de Charles que incomodam sua esposa. Embora direcionada a Charles, a flor que Emma assoprava cai em uma égua imóvel e mal penteada; não coincidentemente, um animal cujas características lembram os principais defeitos do marido: a imobilidade e o descuido com a aparência.

Na cena seguinte, Emma se desespera mais uma vez com a falta de percepção do esposo:

Se Charles tivesse querido, entretanto, se tivesse adivinhado, se o seu olhar, uma só vez, tivesse vindo ao encontro do pensamento dela, parecia-lhe que uma abundância súbita teria se destacado de seu coração, como cai a colheita de uma parreira quando nela se põe a mão. Mas à medida que mais se estreitava a intimidade da vida deles, dava-se um desapego interior que a desligava dele. [...]

Às vezes ela desenhava; e era para Charles uma grande diversão ficar ali, bem de pé, a contemplá-la debruçada sobre a cartolina, piscando para ver melhor o seu trabalho, ou arredondando, no polegar, bolinhas de miolo de pão. Sobre o piano, quanto mais rapidamente os dedos dela corriam sobre ele, mais ele ficava maravilhado. Ela batia nas teclas com aprumo, e percorria de alto a baixo todo o teclado sem se interromper. Assim sacudido por ela, o velho instrumento, cujas cordas vibravam, fazia-se ouvir até os confins da aldeia quando a janela estava aberta, e muitas vezes o bedel do tabelião, que passava pela estrada principal, sem chapéu e de chinelos, pairava para ouvi-la, com a folha de papel na mão. (FLAUBERT, 2017, p. 122).

Essa cena mostra a falta de entendimento de Charles, que não capta a insatisfação da esposa com o casamento e nem consegue ter uma conversa mais profunda sobre desenho e música, se limitando a dizer que tudo é belo. Os movimentos ágeis de Emma no piano, assim como a força que ela põe nas teclas, resultam em um som alto, que é um apelo. Charles, mesmo estando ao lado dela, não capta a mensagem da mulher, mas quem está do outro lado da janela o consegue: o narrador descreve que o bedel, lá fora, tem uma folha de papel na mão enquanto a ouve, do que se deduz que ele escreve algo sobre a cena de angústia e má comunicação que se passa no interior da casa.

Há um trecho do romance em que há a comparação do leitor Charles à leitora Emma:

[Emma] Assinou o La Corbeille, jornal feminino, e o Sylphe des Salons. Ela devorava, sem saltar nada, todos os relatos de primeiras apresentações, de corridas e de vesperais, interessava-se pela estreia de uma cantora, pela abertura de uma loja. Conhecia as modas novas, o endereço dos bons costureiros, os dias de encontro da alta sociedade no Bois de Boulogne ou de Ópera. Estudou, em Eugène Sue, descrições de mobiliário; leu Balzac e Georges Sand, procurando neles lenitivos imaginários para as suas cobiças pessoais. Mesmo à mesa, trazia o livro e virava folhas enquanto Charles comia falando com ela. A lembrança do visconde voltara sempre em suas leituras. Entre ele e as personagens inventadas, ela estabelecia comparações. Mas o círculo de que era ele o centro pouco a pouco se expandiu em torno dele, e essa auréola que ele possuía afastando-se de sua figura, propagou-se ais longe, para iluminar outros sonhos. (FLAUBERT, 2017, p. 141).

Finalmente, para manter-se informado, assinou o La Ruche médicale, jornal novo de que recebera o prospecto. Ele lia um pouco depois do jantar; mas o calor do cômodo, 
junto com a digestão, fazia com que, ao cabo de cinco minutos, pegasse no sono; e ficava ali, com as duas mãos no queixo e os cabelos espalhados como uma crina até o pé da lâmpada. Emma olhava para ele e dava de ombros. Pelo menos ela não tinha com marido um desses homens de ardores taciturnos que trabalham de noite nos livros e que, finalmente, aos sessenta anos, quando chegam os reumatismos, carregam no peito uma penca de medalhas e de condecorações, sobre o terno preto, malfeito. Ela quisera que o nome Bovary, que era seu, fosse ilustre, vê-lo exposto nas livrarias, repetido nos jornais, conhecido por toda a França. Mas Charles não tinha ambição! Um médico de Yvetot, com quem estivera em consulta recentemente, o havia humilhado um pouco, no próprio leito de um doente, diante dos parentes reunidos. Quando Charles lhe contou, à noite, o ocorrido, Emma irritou-se em voz alta com o confrade. Charles comoveu-se com isso. Beijou sua testa com uma lágrima. Mas ela estava exasperada de vergonha, tinha vontade de bater nele., foi ao corredor abrir a janela e aspirou o ar fresco para se acalmar. (FLAUBERT, 2017, p. 145).

Emma lê Balzac com a intenção de achar personagens que compartilhem de suas ambições pessoais. Ela se compara e também compara o marquês de Vaubyessard aos personagens da Comédia Humana. O marquês foi um homem com quem ela esteve apenas uma vez, em um baile, ou seja, trata-se de alguém que ela sequer sabe se seria um marido inferior ou superior a Charles. Essa cena vai ao encontro da teoria de Iser, visto que a leitura de Balzac, por Emma, tem a intenção de encontrar tanto personagens femininas, que realizaram o que ela sonha, quanto personagens masculinos que se pareçam com o marquês. Como defende Iser, as experiências do leitor contribuem para as imagens que surgem no ato da leitura. Balzac pode ter escrito seus livros com intenção de expor a realidade, mas isso não é o suficiente para que todos os leitores apreendam os ensinamentos, até mesmo porque não há uma coincidência nem entre a realidade que o autor viu e a que ele descreveu, quem dirá entre a realidade da leitora e os escritos do romance. Não coincidentemente, no mesmo capítulo em que é dito que Emma lia Balzac, surge o tema ambição, que é tão balzaquiano. A madame Bovary deseja que seu marido tenha ambições e deixa claro que seu marido ideal não seria um homem que lesse muito, mas que ambicionasse se destacar. Mais uma vez, Charles é um mau leitor da realidade, pois não percebe o motivo da irritação da esposa, e é um mau leitor da revista de Medicina, uma vez que dorme enquanto a lê. Nos romances da Comédia Humana, os personagens que cedem à excessiva ambição têm um fim trágico. Todavia, em sua leitura, Emma vê a ambição como algo positivo, independente do fim trágico dos ambiciosos personagens balzaquianos. Mais uma vez confirmando Iser, a experiência de Emma contribui para que ela constitua a imagem da ambição como algo positivo - pois falta ao seu marido, - e não negativo, como expõe Balzac. O desconforto da cena culmina com Emma se direcionando à janela para se entregar a seus devaneios, ou seja, escapar da realidade indesejada. Novamente, Charles não é capaz de analisar que o acotovelamento na janela é um elemento de repetição na vida da mulher e nem é capaz de comparar com seu próprio hábito, quando jovem insatisfeito.

Segue outra cena do cotidiano dos Bovary: um jantar do casal, após a notícia da morte do pai de Charles:

Quando a toalha de mesa foi retirada, Bovary não se levantou. Emma tampouco; e, à medida que ela o encarava, a monotonia desse espetáculo bania pouco a pouco de seu coração qualquer sentimento de piedade. Ele lhe parecia franzino 
nulo enfim, um pobre homem, de todas as maneiras. Como livrar-se dele? Que noitada interminável! Algo estupefaciente como um vapor de ópio a entorpecia. Eles ouviram no vestíbulo o barulho de um bastão nas tábuas do assoalho. Era Hippolyte que trazia as bagagens da senhora. Para descarregá-las, descreveu penosamente um quarto de círculo com a sua perna de madeira.

Ele nem pensa mais nisso! dizia-se ela olhando para o pobre coitado cuja vasta cabeleira vermelha gotejava de suor.

Bovary procurava um trocado no fundo da bolsa; e, sem parecer entender tudo que havia de humilhação na simples presença daquele homem que estava ali, como a acusação personificada de sua incurável inépcia:

- Olha! Você tem um bonito ramalhete! - disse ele ao notar na lareira as violetas de Léon. (FLAUBERT, 2017, p. 366).

Emma não se solidariza com o sofrimento do cônjuge por perder o pai; ao contrário, julga-o ainda mais desprezível em seu sofrimento. Emma espera que Charles reflita sobre a dificuldade de movimento de Hyppolite, resultado do seu erro médico, mas, para ele, dificuldade de movimento não é um problema, uma vez que é, inclusive, sua principal característica. Em sua leitura, o senhor Bovary pensa que a esposa está desconfortável com a morte do sogro e tenta mudar de assunto para que ela não sofra tanto. Entretanto, até nessa mudança ele comete erros, elogiando um ramalhete dado a ela pelo seu amante, Léon. Isso indica que, na leitura que Charles faz de sua realidade, não estão inclusas as imagens de adultério, desprezo e tédio por parte da esposa.

\section{O LEITOR SR. ROUAULT}

Em alguns trechos do romance Madame Bovary, a figura do pai de Emma, o senhor Rouault, aparece com certa semelhança à de Charles. É o caso do planejamento da cerimônia de casamento da filha: "Emma gostaria, ao contrário, de casar à meia-noite, à luz de tochas; mas o pai Rouault não entendeu nada dessa ideia." (FLAUBERT, 2017, p. 103). O pai é descrito de forma semelhante ao marido: um homem que não entende os desejos de Emma e as suas referências a cenas de romances.

Entretanto, há uma cena em que o senhor Rouault se mostra um bom leitor da realidade:

Dois dias depois do casamento, os recém casados se foram. Charles, por causa dos seus doentes, não podia se ausentar por muito tempo. O pai Rouault mandou que os levassem em seu trole e ele próprio os acompanhou até Vassonville. Lá, beijou a filha uma última vez, apeou e retomou seu caminho. Após ter andado uns cem passos, parou e, como visse que o trole se afastava cujas rodas giravam na poeira, lançou um grande suspiro. Depois lembrou-se das suas núpcias, do seu tempo de outrora, a primeira gravidez de sua mulher; estava bem alegre, também ele, no dia em que a levara da casa do pai para a sua, quando a carregava na garupa trotando sobre a neve; pois estava-se na época do Natal e a campina estava toda branca; ela segurava nele com um braço, no outro estava presa a sua cesta; o vento agitava as longas rendas de suas toca cauchesa, que às vezes lhe passava pela boca e quando virava a cabeça, via perto dele, por sobre o ombro, o pequeno rosto rosado que sorria silenciosamente, sob a placa de ouro de seu boné. Para esquentar os dedos, ela os colocava de vez em quando, no peito. Como tudo isso já estava velho! O filho deles, agora, teria trinta anos! Então olhou para trás, nada avistou a nao ser a estrada. Sentiu-se triste como uma casa sem móveis; as ternas lembranças mesclando-se aos pensamentos negros 
no cérebro obscurecido pelos vapores da comilança, teve vontade, num momento, de ir dar uma volta pelos lados da igreja. Como tivesse medo, entretanto, que aquela vista o fizesse ficar mais triste ainda, voltou diretamente para casa. (FLAUBERT, 2017, p. 110 ).

Essa cena é um daqueles momentos do romance em que se tem acesso a um ponto de vista diferente do de Emma, sendo, neste caso, o ponto de vista de seu pai. O senhor Rouault tem um devaneio em que aparece o filho, que faleceu prematuramente. Não por coincidência, a lembrança do filho falecido vem quando Emma está se afastando dele para dar início a uma vida de casada que resultará em sua morte, a qual causará em seu pai sofrimento semelhante à da morte do filho. Nessa cena, a leitura do senhor Rouault marca a antecipação do fim da história. Em acordo com a explanação de Iser, a leitura da realidade pelo senhor Rouault foi baseada em sua experiência da morte de um dos filhos. Fosse uma outra pessoa diante da mesma cena, não faria a mesma leitura.

Há outro momento em que o senhor Rouault aparece associado a Charles, por causar aborrecimento e tédio em Emma:

Pelo fim de fevereiro, o velho Rouault, em lembrança de sua cura, levou pessoalmente ao genro um enorme peru, e ficou três dias em Tostes. Enquanto Charles cuidava de seus doentes, Emma fez-lhe companhia. Ele fumou no quarto, cuspiu na grelha, falou sobre agricultura, novilhos, vacas, aves domésticas e conselho municipal, com um sentimento de satisfação com que ela mesma se surpreendeu. (FLAUBERT, 2017, p. 150-1).

Todavia, para além do tédio da moça, é interessante ressaltar o apego de Rouault às repetições da vida. Quando Charles Bovary lhe prestou serviços médicos, o pai da protagonista deu a ele um peru, de presente. Desde então, o velho fez disso um elemento de repetição de sua vida, uma vez que, mesmo após a morte da filha, ele continua a enviar, para o genro, o mesmo presente na mesma época do ano.

\section{O LEITOR RODOLPHE BOULANGER}

Rodolphe Boulanger, primeiro amante de Emma Bovary, sempre aparece no romance como um homem prático, que não cede aos caprichos da amante e que, por isso, chega a deixá-la irritada. O fim do romance dos dois, quando a senhora Bovary combina com ele uma fuga, mostra que viver um acontecimento tão romanesco com uma amante nunca fez parte dos seus planos. A seguir, a leitura da madame Bovary, pelo senhor Boulanger:

Ele tinha escutado tantas vezes essas coisas, que já não tinham para ele nada de original. Emma era parecida com todas as amantes; e o encanto da novidade, caindo pouco a pouco como uma roupa, deixava ver a nu a eterna monotonia da paixão, que tem sempre as mesmas formas e a mesma linguagem. Ele não distinguia, esse homem tão cheio de prática, a dessemelhança dos sentimentos sob a paridade das expressões. Porque lábios libertinos ou venais tinham murmurado frases iguais, ele só acreditava francamente no candor delas; dever-se-ia, pensava, desconsiderar os discursos exagerados que escondem as afeições medíocres; como se a plenitude da alma não se derramasse às vezes pelas metáforas mais vazias, posto que ninguém, nunca, pode dar a exata medida de suas necessidades, nem de suas concepções, nem de suas dores e que a palavra humana é como um caldeirão trincado onde batemos melodias para fazer os ursos dançarem, quando se quereria enternecer as estrelas. (FLAUBERT, 2017, p. 296). 
Rodolphe analisa as repetições de sua vida, sobretudo as das falas de sua amante, e se questiona sobre a monotonia das expressões de linguagem que tanto já ouvira. Para ele, por trás de todo o exagero nas palavras, há uma mediocridade. Isso mostra a incompatibilidade entre ele e Emma, uma vez que, o que para ela era um ideal de felicidade, para ele era mais uma repetição medíocre. Rodolphe faz uma leitura de sua amante, a qual se entedia com as repetições da sua vida conjugal com Charles, sem perceber que suas falas criam uma repetição de clichés que entediam seu amante da mesma forma que o marido a entedia. Mais uma vez, a leitura do affair como algo monótono está relacionado às experiências de adultério já vividas por Rodolphe, enquanto Emma, diante da mesma situação, vê um caso de amor que se eternizará com a fuga dos dois, baseada em suas experiências literárias.

\title{
O LEITOR LÉON
}

O leitor Léon, a princípio amante em potencial e, posteriormente, segundo amante da protagonista, muito se assemelha à madame Bovary, em sua primeira aparição:

\begin{abstract}
- A minha mulher não cuida disso - disse Charles -; ela prefere, embora se the recomende o exercício, ficar sempre em seu quarto, lendo. - É como eu - replicou Léon -;o que há de melhor, realmente, do que ficar à noitinha no canto da lareira com um livro, enquanto o vento bate nas vidraças, a lamparina queima?...

- Não é mesmo? - disse ela, fixando sobre ele os grandes olhos negros bem abertos.

- Não se pensa em nada - continuou ele -, as horas passam. A gente passeia imóvel por lugares que acredita ver, e o seu pensamento, lançando-se à ficção, brinca nos detalhes ou persegue o contorno das aventuras. Ele sem mescla às personagens; parece que é a gente que palpita sob as roupas.

-É verdade! É verdade! - dizia ela.

- Já lhe aconteceu alguma vez - retomou Léon - encontrar num livro uma ideia vaga que se teve, alguma imagem obscurecida que volta de longe, e como a exposição inteira do seu sentimento mais sutil? -Experimentei isso. - $\quad$ respondeu ela. -É por isso que - disse ele - gosto sobretudo dos poetas. Acho os versos mais ternos do que a prosa, e que eles fazem chorar mais facilmente. -Entretanto, com o tempo, eles cansam - retomou Emma -; e agora, ao contrário, adoro as histórias que se seguem num só fôlego, onde se tem medo. Detesto os heróis comuns e os sentimentos temperados, como existem na natureza.

- De fato - observou o escrivão -, ao não tocar os corações, essas obras se afastam, parece-me, do verdadeiro objetivo da Arte. É tão doce, entre os desencantos da vida, pode evocar, em ideia, nobres personalidades, afeições puras e quadros de felicidade. Quanto a mim, vivendo aqui, longe do mundo, é a minha única distração; mas Yonville oferece tão poucos recursos! (FLAUBERT, 2017, p. 172).
\end{abstract}

Léon emprega todos os clichés esperados ao expressar seu gosto pela leitura. Ele, também, tem o mesmo tédio com o local e despreza todos aqueles com quem convive em Yonville, aos quais ele atribui a culpa pela sua insatisfação com a vida. A chegada da senhora Bovary pareceu ser, para ele, uma possibilidade de uma aventura amorosa, porém duvida da reciprocidade de seus sentimentos:

Léon estava cansado de amar sem resultado; depois começava a sentir aquele desânimo que é causado pela repetição da mesma vida, quando nenhum interesse a norteia e nenhuma esperança a sustenta. Estava tão enjoado de Yonville e dos yonvillenses 
que a vista de certas pessoas, de certas casas, o irritava a ponto de não aguentar mais; e o farmacêutico, embora fosse uma boa pessoa, tornava-se para ele completamente insuportável. Entretanto, a perspectiva de uma situação nova o espantava tanto quanto o seduzia.

Essa apreensão logo virou impaciência, e Paris então agitou para ele, ao longe, a fanfarra de seus bailes de máscaras com o riso de suas mocinhas. (FLAUBERT, 2017, p. 211).

Léon analisa as repetições da vida com tédio e, então, decide se mudar para Paris com a ilusão de viver o que lia em seus livros. A experiência de estar em uma cidade pequena, na qual há poucos acontecimentos, fez com que os romances que se passam em Paris parecessem, para Léon, muito atraentes; tanto que ele até altera a sua vida em função disso.

Estando Léon em Paris, Emma vive o romance com Rodolphe de Boulanger. Quando esse chega ao fim, ela vai a uma peça de teatro e encontra Léon, a partir do que, surge a oportunidade de finalmente viverem a relação extraconjugal que outrora não tiveram coragem. No início da relação, Léon sente uma alegria por estar vivendo uma cena livresca: "Era a primeira vez que comprava flores para uma mulher; e o seu peito, respirando-as, encheu-se de orgulho, como se aquela homenagem que ele destinava a outrem tivesse voltado para ele." (FLAUBERT, 2017, p. 352). Porém, com o tempo de relacionamento, a impressão de Léon se torna diferente:

Léon finalmente jurara nunca mais encontrar-se com Emma; e se censurava por não ter cumprido a palavra, considerando tudo o que aquela mulher ainda poderia atrair-lhe de confusões e de discursos, sem contar os gracejos de seus colegas, que eram feito de manhã, ao pé da lareira. Aliás, ele estava prestes a se tornar primeiro escrivão: era o momento de ficar sério. Renunciava também à flauta, aos sentimentos exaltados, à imaginação, pois todo burguês, no calor da juventude, ainda que fosse um só dia, um minuto, acreditou-se capaz de intensas paixões, de altos empreendimentos. O mais medíocre libertino sonhou com sultanas; cada tabelião carrega em si os escombros de um poeta. (FLAUBERT, 2017, p. 410).

Léon, aparentemente, leu tantos romances de Balzac que parece querer forçar, para sua vida, o processo de aprendizagem pelo qual os personagens passaram. Para isso, ele quis viver uma aventura amorosa, como sendo algo essencial da juventude, mas, sentindo que chegou a fase adulta, conclui que o tempo de ter uma amante e de ser entregue às paixões chegou ao fim e, para romper com o período anterior da vida, deve assumir novos comportamentos, se livrando de tudo que fazia parte da imaturidade. Isso indica que, no caso de Léon, a imagem que ele formou a partir da leitura de sua realidade teve a interferência da sua experiência de leitura dos livros de Balzac.

\section{A LEITORA EMMA}

Fica claro, em Madame Bovary, que a leitura de romances é um hábito da protagonista. A seguir, é proposta a comparação entre a sua leitura dos romances e a sua leitura da vida, começando pelo seguinte pensamento da moça:

Antes de se casar, ela achava ter amor; mas não tendo chegado a felicidade que deveria resultar desse amor, era preciso que ela tivesse se enganado, pensava. E Emma buscava saber o que exatamente se entendia na vida pelas palavras felicidade, paixão e embriaguez, que lhe tinham parecido tão belas nos livros. (FLAUBERT, 2017, p. 114). 
Em O Vermelho e o Negro, está dito que "O amor apaixonado era ainda antes um modelo que se imitava do que uma realidade." (STENDHAL, 2015, p. 349). Para Emma, ao contrário, o amor apaixonado, repleto de "felicidade, paixão e embriaguez" era algo real, descrito nos romances, e que deveria ser encontrado na realidade. A sua leitura da vida é prejudicada pela busca de elementos específicos, os quais ela nunca encontrou, ou, se encontrou, não permaneceram por muito tempo.

No capítulo do baile em Vaubyessard, tão importante no romance, Emma encontra um ancião que nada mais é que uma repetição de Charles, porém em idade mais avançada:

Entrementes, na outra extremidade da mesa, sozinho entre todas aquelas mulheres, curvado sobre seu prato cheio e com o guardanapo preso às costas como uma criança, um ancião comia, deixando cair da boca gotas de molho. [...] Era o sogro do marquês [..]. Levara uma ruidosa vida de dissipação, cheia de duelos, de apostas, de mulheres raptadas, devorara sua fortuna e assustara toda a família. Um criado, atrás de sua cadeira, dizia-lhe em voz alta, ao ouvido, os nomes dos pratos que ele, gaguejando, indicava com o dedo; e a todo momento os olhos de Emma voltavam automaticamente para aquele ancião de lábios caídos, como a algo de extraordinário e de augusto. Ele vivera na Corte e dormira na cama das rainhas! (FLAUBERT, 2009, p. 56-7).

O ancião, semelhante a Charles, é uma figura burlesca, com um guardanapo colocado de forma errada nas costas. Porém, o fato de o homem ter vivido na corte e ter dormido com rainhas anulou a capacidade de Emma de fazer uma boa leitura da realidade e perceber a repetição que a figura do velho representava.

Entretanto, em outras ocasiões, Emma consegue fazer uma boa leitura das repetições de sua vida:

Era a quarta vez que ela dormia em um lugar desconhecido. A primeira tinha sido no dia de sua entrada no convento; a segunda, a de sua chegada a Tostes; a terceira, em Vaubyessard; a quarta era esta; e acontecia que cada uma acabara por abrir em sua vida como que uma fase nova. Não acreditava que as coisas se pudessem apresentar as mesmas em lugares diferentes e, visto que a porção vivida tinha sido má, sem dúvida o que restava a consumir seria melhor. (FLAUBERT, 2017, p. 174).

Embora quase o tempo todo as repetições a entediassem, madame Bovary, nessa cena, analisa os elementos que se repetem, mas não com um tédio, e sim, pensando na mudança de função de cada um deles. Todavia, essa leitura positiva das repetições da vida não perdura. Basta ler a cena do seu primeiro passeio com Léon, quando ele ainda era um amante em potencial:

A sra. Bovary disse que estava indo visitar a filha, mas começava a se sentir cansada. - Se...- retomou Léon, que não ousava prosseguir.- O senhor vai fazer algo em algum lugar? - perguntou ela., diante da resposta do escrivão, ela pediu-lhe que a acompanhasse. Já naquela tarde, isso ficou conhecido em Yonville, e a sra. Tuvache, mulher do prefeito, declarou diante de sua criada que a sra. Bovary estava se comprometendo.

Para chegar à casa da ama era preciso, depois da rua, virar à esquerda, como para tomar a direção do cemitério, e seguir, entre casinhas e largos, um pequeno caminho ladeado de alfeneiros. Eles estavam floridos e as verônicas também, as rosas caninas, as urtigas, as urzes leves que se lançavam das moitas. Pelos furos das sebes, avistavam-se, nas mansardas, algum porco sobre o estrume, ou vacas encabrestadas, esfregando os chifres no tronco das árvores. Ambos, lado a lado, caminhavam devagar, 
ela se apoiando nele e ele segurando o passo que media sobre os dela; diante deles, um enxame de moscas girava, zumbindo no ar quente. (FLAUBERT, 2017, p. 182). Eles se encontraram quando ela ia à casa da ama de sua filha Berthe. Léon balbuciava, o que remete à atitude de Charles tanto na cena de sala de aula quanto na do pedido de casamento. Todavia, assim como na cena do ancião em Vaubyessard, Emma não se atenta à repetição, não percebendo a semelhança entre o marido e o jovem rapaz, o qual ela considera admirável. Emma ignora os elementos "porco sobre o estrume", "vacas encabestradas esfregando chifres", moscas "zumbindo no ar quente" como componentes da realidade, tentando obter, do momento com Léon, uma experiência de amor parecida com suas leituras romanescas.

\section{Em outro momento do romance, Emma apresenta sua leitura do que é o amor:}

Quanto a Emma, não se interrogava para saber se o amava. O amor, acreditava ela, devia chegar de repente, com grandes brilhos e fulgurações - tufão dos céus que cai sobre a vida, revira-a, arranca as vontades como folhas e carrega para o abismo o coração inteiro. Não sabia que, no terraço das casas, a chuva faz lagos quando as calhas estão entupidas, e ela permaneceu assim em sua segurança, quando descobriu subitamente uma rachadura na parede. (FLAUBERT, 2017, p. 192).

Emma continua presa aos devaneios e ao conceito romanesco de amor, ignorando a realidade ao seu redor, a qual é simbolizada pelo problema da calha que pode se desenvolver e acarretar incômodos maiores. O fim do capítulo, em suspensão, indica que Emma permaneceu em seu devaneio e não se atentou a algo da realidade que carecia de um olhar para ser consertado.

Adiante no romance, Emma tem a brilhante ideia de tentar a leitura de gêneros mais sérios:

Tentou fazer leituras sérias da história e da filosofia. [...] Mas acontecia com as suas leituras o mesmo que com suas tapeçarias que, todas começadas, entulhavam o seu armário; ela as pegava, abandonava-as, passava a outras. (FLAUBERT, 2017, p. 220).

Isso mostra que leituras sobre fatos reais, como é o caso dos livros de história, a entediavam, levando-a a interrompê-las. O mesmo acontece em sua vida: quando o relacionamento com os amantes passa daquele início romântico, ela se entedia.

Sobre o período romanesco de Emma com seus amantes, há os trechos a seguir. O primeiro é a cena do primeiro beijo de Emma e Rodolphe:

As sombras da noite baixaram; o sol horizontal, passando por entre os galhos, ofuscava-lhe os olhos. Aqui e acolá, ao redor dela, nas folhas ou no chão, manchas luminosas tremiam, como se colibris, voando, tivessem espalhado as suas plumas. $\mathrm{O}$ silêncio estava por toda parte; algo suave parecia sair das árvores; ela sentia o coração, cujos batimentos recomeçavam, e o sangue circular em sua carne como um rio de leite. Então ouviu bem ao longe, para além do bosque, sobre as outras colinas, um grito vago prolongado, uma voz que se arrastava, e ela escutava silenciosamente, mesclando-se como uma música às últimas vibrações de seus nervos comovidos. Rodolphe, de charuto entre os dentes, consertava com o canivete uma das duas rédeas arrebentada. (FLAUBERT, 2017, p. 261).

Emma teve várias sensações no primeiro beijo de Rodolphe. $\mathrm{O}$ amante, por sua vez, consertava uma rédea, o que mostra que ele se atentava a um problema prático, coisa que 
Emma não fazia, haja vista ela não ter percebido o problema das rachaduras na parede de sua própria casa. Após o beijo, Emma, estando sozinha, pensa na sua nova condição de amante:

\begin{abstract}
Mas, ao se ver no espelho, ficou espantada com o seu rosto. Nunca tinha tido os olhos tão grandes, tão negros, nem de tamanha profundidade. Alguma coisa de sutil espalhada por sua pessoa a transfigurava.[...]. Ela repetia a si mesma: "Eu tenho um amante! Um amante!", deleitando-se com essa ideia como com de outra puberdade que lhe tivesse advindo. Ia finalmente possuir aquelas alegrias do amor, aquela febre da felicidade que já tinha perdido as esperanças. (FLAUBERT, 2017, p. 262).
\end{abstract}

Em sua ilusão, Emma pensa que o início da relação com o senhor Boulanger representa o ápice de sua vida e, até mesmo, crê que, fisicamente, já há alterações eu sua própria aparência, decorrentes do romance recém iniciado. Isso se assemelha à cena em que Léon se alegra por estar portando um buquê para entregar a uma amante. Cabe, aqui, a citação de René Girard, cujas palavras bem explicam o sentimento de Emma nas cenas acima:

Essas personagens não conseguem se igualar ao modelo que propuseram para si. Entretanto, o amor por si próprias lhes proíbe de confessar a si mesmas sua impotência. Cegando seu juízo, ele as impele para a postura de enganar a si próprias e de se identificar em sua própria visão com a imagem pela qual elas substituíram sua pessoa. (GIRARD, 2009, p. 88).

Emma segue iludida de ter se igualado ao modelo de si que ela mesma propôs, até que, criando uma situação de falsa irritação para que Rodolphe a bajulasse, o amante não tem a reação esperada. Por mais irrisório que isso fosse, representou, para Emma, um acontecimento sério o suficiente para despertar o desejo de ser fiel ao marido. Porém, ciente de que precisaria de algo que tornasse Charles mais admirável, sugere a ele que tente curar os pés tortos do personagem Hyppolite. Após a cirurgia, aparentemente bem-sucedida, Emma muda sua atitude em casa:

Depois Charles, tendo prendido o doente no motor mecânico, voltou para casa, onde Emma, ansiosa, esperava-o à porta. Ela pulou em seu pescoço; puseram-se à mesa; ele comeu muito e quis até, na hora da sobremesa, uma xícara de café, extravagância que só se permitia aos domingos quando havia visitas.

A noite foi encantadora, cheia de conversas, de sonhos em comum. Falaram da fortuna futura, das melhorias a serem introduzidas na casa; ele via estender-se a sua consideração, o seu bem-estar aumentar, a sua mulher a amá-lo sempre; e ela se achava feliz por refrescar-se num sentimento novo, mais sadio, melhor, enfim, por experimentar alguma ternura por esse pobre moço que a queria tanto. A ideia de Rodolphe, por um momento, passou-lhe ela cabeça pela cabeça; mas os seus olhos se voltaram para Charles: ela notou até com surpresa que ele não tinha os dentes feios. (FLAUBERT, 2017, p. 281).

A leitura de toda a cena de jantar, com o marido, foi positiva por Emma pensar estar casada com um inovador da Medicina de Yonville A chegada do marido após um dia de traba1ho, assim como o jantar, são acontecimentos cotidianos, porém apenas neste dia ela vê como algo bom. Ao se lembrar do amante, Emma faz uma nova leitura do marido, percebendo que, supreendentemente, os seus dentes não eram feios. 
Em seu segundo relacionamento extraconjugal, Emma tem uma impressão inicial semelhante à que teve em seu relacionamento com Rodolphe, porém, em sua má leitura, diz ser a primeira vez que tem tal experiência:

Ela saboreava pela primeira vez a inexprimível delicadeza das elegâncias femininas. Nunca tinha encontrado essa graça de linguagem, essa reserva de roupa, essas poses de pomba adormecida. Admirava a exaltação de sua alma e as rendas de sua saia. Aliás, acaso não era uma mulher do mundo, e uma mulher casada! Uma verdadeira amante enfim?

Pela diversidade de seu humor, ora místico, ora alegre, tagarela, taciturno, exaltado, sossegado, ela ia recordando a ele mil desejos, evocando instintos ou reminiscências. Ela era a apaixonada de todos os romances, a heroína de todos os dramas, o vago ela de todos os volumes de versos. Ele reencontrava em suas espáduas a cor de âmbar da odalisca no banho, tinha o corpete longo das castelãs feudais; parecia-se também com a mulher pálida de Barcelona, mas estava acima de todo anjo!

Muitas vezes, olhando para ela, parecia-lhe que a sua alma, escapando rumo a ela, expandia-se como uma onda sobre o contorno de sua cabeça e descia arrastada na brancura de seu peito. (FLAUBERT, 2017, p. 382).

A sua felicidade consiste em se sentir comparável a figuras das pinturas, das poesias e dos romances. A leitura do trecho acima fica mais interessante quando lidas, em seguida, as impressões da mesma mulher sobre o mesmo relacionamento, tempos depois:

Ela estava tão enfarada dele quanto ele estava fatigado dela. Emma reencontrava no adultério todas as platitudes do casamento.

Mas como poder livrar-se dele? Depois, por mais que se sentisse humilhada com a baixeza de tal felicidade, mantinha-a por hábito ou por corrupção; e, a cada dia, mais se encarniçava nela, bloqueando toda felicidade por querê-la demasiado grande. Ela acusava Léon de suas esperanças frustradas, como se ele a tivesse traído; e até desejava uma catástrofe que levasse à separação, pois que não tinha coragem de decidir-se. (FLAUBERT, 2017, p. 410).

A insatisfação com Léon levou Emma a refletir sobre sua vida desde a adolescência, se questionando sobre quando havia sido feliz:

Um dia em que eles tinham se separado cedo e que ela vinha voltando sozinha pela avenida, avistou os muros de seu convento; então sentou-se num banco, à sombra dos olmeiros. Que calma naquele tempo! Como anelava os inefáveis sentimentos do amor que tentava, segundo os livros, imaginar!

Nos primeiros meses de casamento, os seus passeios a cavalo na floresta, o visconde que valsava, e Lagardy cantando, tudo voltou a passar diante de seus olhos.... E Léon pareceu-lhe de repente tão distante quanto os outros.

- Eu o amo entretanto! - dizia-se ela.

Não importa! Não estava feliz, nunca tinha estado. De onde vinha então insuficiência da vida, essa podridão instantânea das coisas em que ela se apoiava? Mas, se havia em algum lugar um ser forte e belo, uma natureza valorosa, cheia, ao mesmo tempo, de exaltação e de refinamento, um coração de poeta sob a forma de anjo, lira com cordas de bronze, soando para o céu epitalâmios elegíacos, por que, porventura, ela não o encontraria? Oh! Que impossibilidade! Nada, aliás, vali a pena de uma procura; tudo mentia! Cada sorriso escondia um bocejo de tédio, cada alegria uma maldição, cada prazer o seu desgosto, e os melhores beijos não deixavam nos lábios senão uma irrealizável vontade de uma volúpia mais alta. Um estertor metálico arrastou-se pelos ares e quatro badaladas se fizeram ouvir no 
sino do convento. Quatro horas! E parecia-lhe que estava ali naquele banco, havia uma eternidade. Mas um infinito de paixão pode caber em um minuto, como uma multidão num pequeno espaço. (FLAUBERT, 2017, p. 403).

Emma nota que a memória de felicidade que ela tem é de suas leituras no convento, e começa a pensar que não conseguirá encontrar, no mundo, o que ela lia nos romances, de modo que não há mais como buscar a felicidade almejada. Essa conclusão contribui, significativamente, para a sua decisão de encerrar sua própria vida. Após tomar arsênico, Emma pensa: "Ah, é bem pouca coisa, a morte!, pensava; vou adormecer, e tudo estará acabado!" (FLAUBERT, 2017, p. 440). Uma vez que, em vida, não conseguiu realizar o que lera nos romances, Emma tem a última esperança de que possa então, na morte, viver um episódio romanesco.

As leituras de Emma, apresentadas nesta seção, mostram que, assim como seu amante Léon, as imagens da leitura de sua realidade são pautadas em suas experiências literárias, o que é análogo ao que Iser defende sobre as leituras das ficções serem dependentes das experiências de vida do leitor.

\section{CONCLUSÃO}

Após a análise dos excertos do romance, conclui-se que a teoria de Wolfgang Iser sobre o ato de leitura de fato se aplica não só a leitores reais da ficção, mas a leitores ficcionais da realidade e das ficções. Os personagens de Flaubert, ao lerem a ficção de Balzac, um autor tão explicativo da realidade, não conseguem apreender a realidade que pretendia Balzac, visto que cada um associa os personagens da Comédia Humana ao que eles são ou gostariam de ser. Os personagens, ao lerem a realidade, têm leituras distintas de uma mesma cena, baseadas em suas experiências de vida ou de leitura, o que prova que a teoria do ato de leitura se aplica não só à leitura da ficção por pessoas reais, mas também à leitura da realidade por personagens ficcionais.

\section{ACT OF READING, ACTS OF IMAGINATION: READERS CHARACTERS IN MADAME BOVARY}

ABSTRACT: This work presents Wolfgang Iser's theories about the act of reading and it relates them to Flaubert's novel Madame Bovary. The goal is showing that both the reading of reality and the reading of the fiction involve the personal experiences, that interfer in the acts of imagination of each character. For that, it presents the excerts of the novel Madame Bovary in what the theme of reading is discussed. The conclusion was that, indeed, the characters of the French classic novel read the fictions and the reality according to their experiences, and the experiences can have been acquired by of something they have lived or of something they have read.

KEYWORDS: Act of reading. Readers. Fiction. Reality.

\section{REFERÊNCIAS}

BROOKS, Peter. Reading for the plot: design and intention in narrative. New York: Harvard University Press, 1992.

FLAUBERT, Gustave. Cartas Exemplares. Tradução de Carlos Eduardo Machado. Rio de Janeiro: Imago, 2005.

FLAUBERT, Gustave. Madame Bovary. Tradução de Mário Laranjeira. São Paulo: Penguin Classics Companhia das Letras, 2007.

GIRARD, René. Mentira romântica e verdade romanesca. São Paulo: É realizações, 2009. ISER, Wolfgang. O Ato da leitura: uma teoria do efeito estético. São Paulo: Editora 34, 1996. 
KENNER, Hugh. Flaubert, Joyce and Beckett: The Stoic Comedians. London: Dalkey Archive Press, 2005.

STENDHAL. O Vermelho e o Negro: Crônica do século XX. Tradução de Raquel Prado. São Paulo: Cosac Naify, 2015.

Data submissão: 05/05/2020

Data aprovação:09/09/2020 